\title{
ROLE OF THE THYMUS IN IMMUNE REACTIONS IN RATS
}

\author{
I. The Immunologic Response to Bovine Serdm Albumin (Antibody \\ Formation, ARthus Reactivity, and Delayed Hypersensitivity) in \\ Rats Thymectomized or Splenectomized at Various Times after Birth* \\ BY BRANISLAV D. JANKOVIČ, $\ddagger$ M.D., BYRON H. WAKSMAN,§ M.D., \\ AND BARRY G. ARNASON,\| M.D. \\ (From the Neurology Research Laboratory, Massachusetts General Hospital, and the \\ Department of Bacteriology and Immunology, Harvard Medical School, Boston) \\ Plate 12
}

(Received for publication, April 11, 1962)

Studies on the immunologic function of lymphatic organs have concerned themselves successively with the role of the spleen, lymph nodes, marrow, gastrointestinal lymphatic tissue, thymus, and bursa of Fabricius (an analogue of the thymus found in birds). The formation of antibody in spleen, lymph nodes, marrow, and gastrointestinal lymphatic tissue (e.g. appendix) has been demonstrated either directly, by the use of the immunofluorescent technique, indirectly, by the use of cells derived from these organs to transfer antibodyforming capacity passively to tissue cultures or to unimmunized recipients, or by extirpation experiments (reviewed in references 1 and 2). Similarly the role of these organs, lymph nodes in particular, as a source of the "sensitized cells" responsible for delayed sensitivity has been elucidated by extirpation or by passive transfer (reviewed in references 3 and 4 ). With regard to the thymus and the bursa of Fabricius, the available evidence (reviewed in reference 5) suggests that they are not directly concerned in the manufacture of antibody or sensitized cells but may play some indirect role. Few extirpation experiments have thus far been reported.

The mammalian thymus is derived from the entoderm of the third pharyngeal pouch. It contains, at first, reticular cells of epithelial origin and, later, cells resembling small lymphocytes which have been shown to be derived from these epithelial precursors $(5 a)$. Thymectomy

* Supported by Grants B-919 and E-1257 of the National Institutes of Health, and Grant 268 of the National Multiple Sclerosis Society. These data were presented in preliminary form before the 46th Annual Meeting of the American Association of Immunologists, Atlantic City, New Jersey, April, 1962.

$\ddagger$ Present address: University of Belgrade, Faculty of Pharmacy, Microbiological Institute, Belgrade, Yugoslavia.

$\$$ National Neurological Research Foundation Scientist.

|| National Multiple Sclerosis Society Fellow, 1959-61. Present address: Service de Chimie Microbienne, Institut Pasteur, Paris. 
ot rabbits aged 3 weeks or more does not alter their capacity to make antibody against protein antigens (6-8). Fichtelius $e t$ al. (9) have presented data to show that thymectomy of young adult guinea pigs may lead to some impairment of ability to give a primary antibody response but that it does not affect the secondary response. Archer and Pierce have shown that rabbits thymectomized at birth may have, thereafter, a diminished capacity to make antibody (10). No experiments on delayed sensitization to protein antigens in thymectomized animals have been reported. However, several recent publications (11-13) have indicated that homograft rejection is markedly delayed in animals thymectomized at or shortly after birth. Thymectomy in adult life has not been shown to affect this process.

The bursa of Fabricius in birds resembles the mammalian thymus closely, both anatomically (14) and in histochemical properties (15). It also produces small lymphocytes derived from epithelial precursors (14). Birds have a thymus in addition to the bursa. Surgical extirpation of the bursa during the 1st week of life results in permanently impaired capacity to make antibody (16). Bursectomy 5 weeks after hatching results in only slight decrease of antibodyforming capacity and bursectomy after 5 weeks does not affect it. Recently Wolfe and his coworkers have found that bursectomy does not influence homograft rejection (17). Thymectomy of newly hatched chickens, on the other hand, may slow homograft rejection (17). Testosterone and certain modified testosterones, such as 19-nor-testosterone, when applied to 5 day eggs suppress the development of the bursa of Fabricius. Chemical bursectomy with such agents markedly inhibits antibody-forming capacity $(16,18)$ and is said to reduce the ability to reject homografts (19). Unfortunately this drastic treatment causes a reduction in spleen and thymus size, in addition to suppression of the bursa of Fabricius, and yields underweight birds suffering from chronic diarrhea, which seldom reach adulthood (16).

The experiments to be reported in the present paper show that both antibody formation (and Arthus reactivity) and delayed sensitization are impaired in thymectomized rats immunized with bovine serum albumin in a standard manner.

\section{Materials and Methods}

Surgical Technique. -1 to 5 day old Sprague-Dawley rats ${ }^{1}$ were immobilized in filter paper and placed in a glass container immersed in ice water. In 15 to 20 minutes, deep hypothermic anesthesia was attained: spontaneous respirations ceased and the heart rate slowed to about 10 beats per minute. At this juncture, animals were taken from their container and placed supine on a small animal board. With the use of clean, but not sterile, technique the chest was opened by a sternal splitting incision. Retraction of the overlying muscle exposed the thymus filling the anterior mediastinum. The thymus was freed from its attachments to the mediastinal pleura, pericardium, and underlying great vessels by blunt dissection and delivered, generally intact but occasionally piecemeal. After washing the mediastinum with sterile Hanks' solution the manubrium was approximated with one or two 6-0 silk sutures, and the skin incision closed with three or four interrupted sutures. Bleeding was generally minimal. With practice, we were able to reduce operative mortality to 10 to 20 per cent. Sham-operated litter mates were handled in an identical fashion except that the thymus was left in situ. Initially, nonoperated litter mates were subjected to the anesthetic procedure but this was found to be an unnecessary precaution.

In some experiments, rats were thymectomized at 2 to 3 weeks of age. The procedure was identical to that indicated above. Thymectomy of older rats, for technical reasons, has not been possible. Thymectomy of adult guinea pigs is, by contrast, a simple matter because the

${ }^{1}$ Obtained from the Charles River Breeding Laboratory, Brookline, Massachusetts. 
thymus in this species is wholly cervical in location. Young adult, Hartley strain guinea pigs were operated upon under ether anesthesia. A midline incision was made from the angle of the mandible to the sternal notch, to reveal the thymus occupying its superficial position in the lower neck. The organ was dissected free and removed intact, and the wound closed with Michel clips. No attempt was made to locate and remove the accessory thymuses commonly found in the guinea pig (20). Sham-operated animals were handled in an identical fashion, except that the thymus was left in situ. There was no mortality.

Splenectomy was also carried out on newborn Sprague-Dawley rats under hypothermic anesthesia. The abdomen was entered by a transverse left flank incision and the spleen, after being freed from the stomach, was removed intact. Bleeding was minimal. The wound was closed with interrupted silk sutures.

Postoperative Care.-Animals were kept at room temperature until respirations and activity had returned to normal. They were then returned to their mothers. Rats were weaned and the sexes separated at 21 to 25 days. They were handled in our routine fashion, no special precautions with regard to infection being taken. They were fed Purina laboratory chow and water ad libilum. All animals, both thymectomized and controls, were weighed from time to time on a standard small animal scale.

Sensitization and Testing of Rats with Bovine Serum Albumin. -8 week old thymectomized rats and litter mate controls were sensitized to bovine serum albumin (BSA) by a single injection of $0.1 \mathrm{ml}$ of antigen in complete adjuvant into the left hind foot-pad. The adjuvant mixture was made up of 10.0 volumes of saline containing $B S A,{ }^{2} 1.5$ volumes of arlacel $A,{ }^{3} 8.5$ volumes of bayol F, and killed tubercle bacilli ${ }^{5}$ at a final concentration of $3 \mathrm{mg} / \mathrm{ml}$, emulsified to give a relatively stable water-in-oil emulsion. The $0.1 \mathrm{ml}$ dose contained $0.5 \mathrm{mg}$ BSA. Only thymectomized rats which had shown a consistently good weight gain were sensitized. All animals were skin-tested at approximately 10 and again at 20 days with $30 \mu \mathrm{g}$ crystalline BSA in $0.1 \mathrm{ml}$ saline, injected intradermally in the shaved flank. Arthus reactions were read at 4 hours. The diameter and degree of gross edema and hemorrhage were recorded; and, in some instances, the lesions were biopsied. Delayed reactions (21) were read at 24,48 , and 72 hours, and the diameter and degree of induration (graded from 0 to +++ ) recorded.

Sensitization and Testing of Adult Guinea Pigs with Egg Albumin.-2 weeks following thymectomy or sham operation, adult guinea pigs were sensitized (22) to egg albumin (Ea) by injecting $0.1 \mathrm{ml}$ of specific precipitate in complete adjuvant intradermally over the sternum. The specific precipitate was prepared from crystalline $\mathrm{Ea},{ }^{6}$ precipitated at two times equivalence with rabbit anti-Ea and washed three times. The $0.1 \mathrm{ml}$ dose contained $3.0 \mu \mathrm{g}$ of antigen protein. All animals, 9 days after sensitization, were depilated with nair, a commercial depilatory, and skin-tested by intradermal injection of 3.0 and $0.3 \mu \mathrm{g}$ doses of Ea in $0.1 \mathrm{ml}$ saline. Delayed reactions were read at 24 hours, and the diameter of erythema and degree of induration recorded. There was no hemorrhage or necrosis. No reaction of the Arthus type preceded the delayed reaction.

Bleedings.-Blood for antibody determinations and electrophoresis was obtained by cardiac puncture before sensitization and 3 and 4 weeks after. After clotting and centrifugation, the serum obtained was stored at $-20^{\circ}$ for subsequent study.

Antibody Determinations. - For hemagglutination, all rat sera were heated at $56^{\circ} \mathrm{C}$ for 25 minutes and absorbed overnight at $4^{\circ} \mathrm{C}$ with thoroughly washed sheep red blood cells. Sheep

${ }^{2}$ Crystalline bovine serum albumin, Pentex Inc., Kankakee, Illinois.

${ }^{3}$ Mannide monooleate, obtained from Atlas Powder Co., Wilmington, Delaware.

4 A light mineral oil, obtained from Esso Standard Oil Co., Linden, New Jersey.

5 Kindly provided by Dr. I. S. Danielson, Lederle Laboratories, Pearl River, New York.

- Crystalline egg albumin, Armour. 
erythrocytes were formalinized according to the method of Csizmas (23) and tanned by the method of Stavitsky (24). Twice washed cells were sensitized for 1 hour at room temperature with BSA (0.5 mg BSA per $\mathrm{ml}$ of 1/40 tanned cell suspension) before dilution to make up a 1 per cent suspension. Titration was performed by a modified Takátsy microtitration technique. The plastic plates were kept overnight at $4^{\circ} \mathrm{C}$ prior to final reading. Preliminary testing of the system with known rat anti-BSA sera assured reproducible titers. Unknown sera were tested in duplicate to ensure accurate end-point determinations.

For determination of heteroagghtinins, human erythrocytes of blood group $O$, as well as rabbit, sheep, mouse, and guinea pig blood samples were collected in Alsever's solution, the red cells washed twice, and 1 per cent suspensions prepared. Agglutination was carried out in $7 \times 45 \mathrm{~mm}$ tubes by mixing each serum, in serial doubling dilutions, with equal volumes of washed erythrocytes of each type and allowing the tubes to stand for 3 hours at room temperature. Readings were performed microscopically by gentle transfer of each tube's content to a microscope slide and examination under low power. Agglutination was scored as 0 to,+++++ being taken as the end-point of antibody activity.

For gel diffusion, the basin technique of Ouchterlony was used (25). Wells were cut in a 2 to $3 \mathrm{~mm}$ layer of "purified" agar (Difco) 1 per cent on a glass plate. BSA ( $50 \mathrm{mg}$ protein $/ \mathrm{ml}$ ) was placed in the center well. Plates were kept at room temperature in a moist chamber and read, and in some instances photographed, at 24 hours.

Electrophoresis.-Paper electrophoresis was carried out on $2.5 \times 12 \mathrm{~cm}$ cellulose acetate strips in veronal buffer, $\mathrm{pH} 8.6$ and 0.1 ionic strength. Strips were run for 2 hours at 175 volts and $10 \mathrm{ma}$, then dried and stained with Ponceau $S$ red. The distribution of protein fractions was measured on a Beckman-Spinco densitometer, model R.B., and the percentage represented by each major protein fraction calculated by standard methods.

Sera from two rats with high anti-BSA antibody titers were pooled. Anti-BSA was precipitated from a $1.0 \mathrm{ml}$ aliquot of pooled serum by successive daily additions of BSA, followed each time by standing overnight at $4^{\circ} \mathrm{C}$ and centrifugation, continued until equivalence had been closely approached (three additions of BSA, total $100 \mu \mathrm{g}$ ). The control serum, after dilution with a volume of saline equal to that added to the antibody-depleted serum, was compared with the latter by moving boundary electrophoresis in veronal buffer $\mathrm{pH} 8.6$ at an ionic strength of 0.1 .

Injection of Tissue Homogenates.--In one experiment with rats thymectomized at birth, thymuses and spleens from normal 75 to $150 \mathrm{gm}$ Sprague-Dawley rats were homogenized in a Potter-Elvehjem homogenizer and the homogenates suspended in saline. $1.5 \mathrm{ml}$ of a freshly prepared 10 per cent suspension ( $150 \mathrm{mg}$ thymic or splenic tissue) was administered intraperitoneally to recipient thymectomized or control rats 2 days before sensitization to BSA and again 1, 4, and 7 days after sensitization.

Banal Inflammation and Spread of Dye through the Tissues.-Four thymectomized and five sham-operated rats received an intradermal injection in one flank of $0.05 \mathrm{ml}$ turpentine (1:20 in olive oil). The resultant inflammatory response (induration, erythema, and central necrosis) was read at 20 minutes, 2,6 , and 24 hours. The same animals also received $0.1 \mathrm{ml}$ 0.5 per cent Evans blue injected intradermally in the opposite flank, and the spread of dye (diameter of the blue spot) was measured at 20 minutes, 2, 6, and 24 hours.

Postmortem.-All rats were autopsied at the end of experimentation. Lymph nodes and spleen were taken in every animal for histologic examination. The mediastinum was inspected for residual thymus, and all tissue which could conceivably be thymic was removed and examined microscopically. The great majority of thymectomized animals had no residual thymus. However, thymectomy was considered satisfactory if less than $100 \mathrm{mg}$ residual thymus was found. 


\section{RESULTS}

Growth and Development.-Save for the exceptions noted below, the health of thymectomized rats was excellent. Text-fig. 1 illustrates weight-gain curves of representative thymectomized, sham-operated, and non-operated rats of both sexes. Thymectomized and sham-operated animals gained weight steadily and equally, although, in some litters, they tended to be slightly lighter than non-operated controls. Only animals which followed this course were used for subsequent experimentation.

"Wasting Disease."-In about 25 per cent of litters, thymectomized rats after an initial period of normal growth began to fail. There was a failure to gain weight for several days, followed by a gradual, but accelerating weight loss leading to cachexia and death in from 10 to 20 days. The onset of this illness occurred as early as 20 days in some litters, as late as 60 days in others (Text-fig. 2). Rats afflicted with wasting disease became lethargic, pallid, and flabby to the touch and their hair became coarse and matted. In some litters this illness eventually killed every thymectomized member, even while shamoperated and non-operated litter mates continued to gain weight in the usual fashion (center group in Text-fig. 2). However, in some afflicted litters, certain rats proven at postmortem to have been without thymus, escaped this illness. Wasting disease was not observed in rats thymectomized at 2 to 3 weeks of age.

Arthus Reactions to BSA and Antibody Determinations.-Rats, sensitized by foot-pad injection of BSA in adjuvant and skin-tested with $30 \mu \mathrm{g} \mathrm{BSA}$, were found to develop Arthus reactions closely comparable to the Arthus response in other species. In the gross, there were pale, edematous lesions, often with a small central area of hemorrhage, maximal at 3 to 4 hours. Microscopically, there was massive subcutaneous edema with extensive infiltration of polymorphonuclear leukocytes and some hemorrhage in the deep dermis, muscle, and subcutaneous connective tissue (Fig. 1).

Arthus reactions were sharply reduced in animals thymectomized shortly after birth and sensitized at 8 weeks (Table I). At 9 to 12 days, none of nineteen thymectomized rats had positive Arthus reactions while controls gave responses of maximal size. By 19 to 21 days, the thymectomized animals could be divided into two groups: one, in which Arthus reactivity had still not appeared, and a second, in which Arthus reactivity approached that of control animals. Hemagglutinating antibody titers were low or insignificant at 21 days in the first group, and were unchanged a week later when the experiment was terminated. No precipitating antibody could be found by gel diffusion in the sera of these animals. In the Arthus-positive group, hemagglutinating antibody titers were comparable to those of control animals and precipitating antibody was present by 3 weeks (Text-fig. 3). Thymus or spleen homogenates were given 


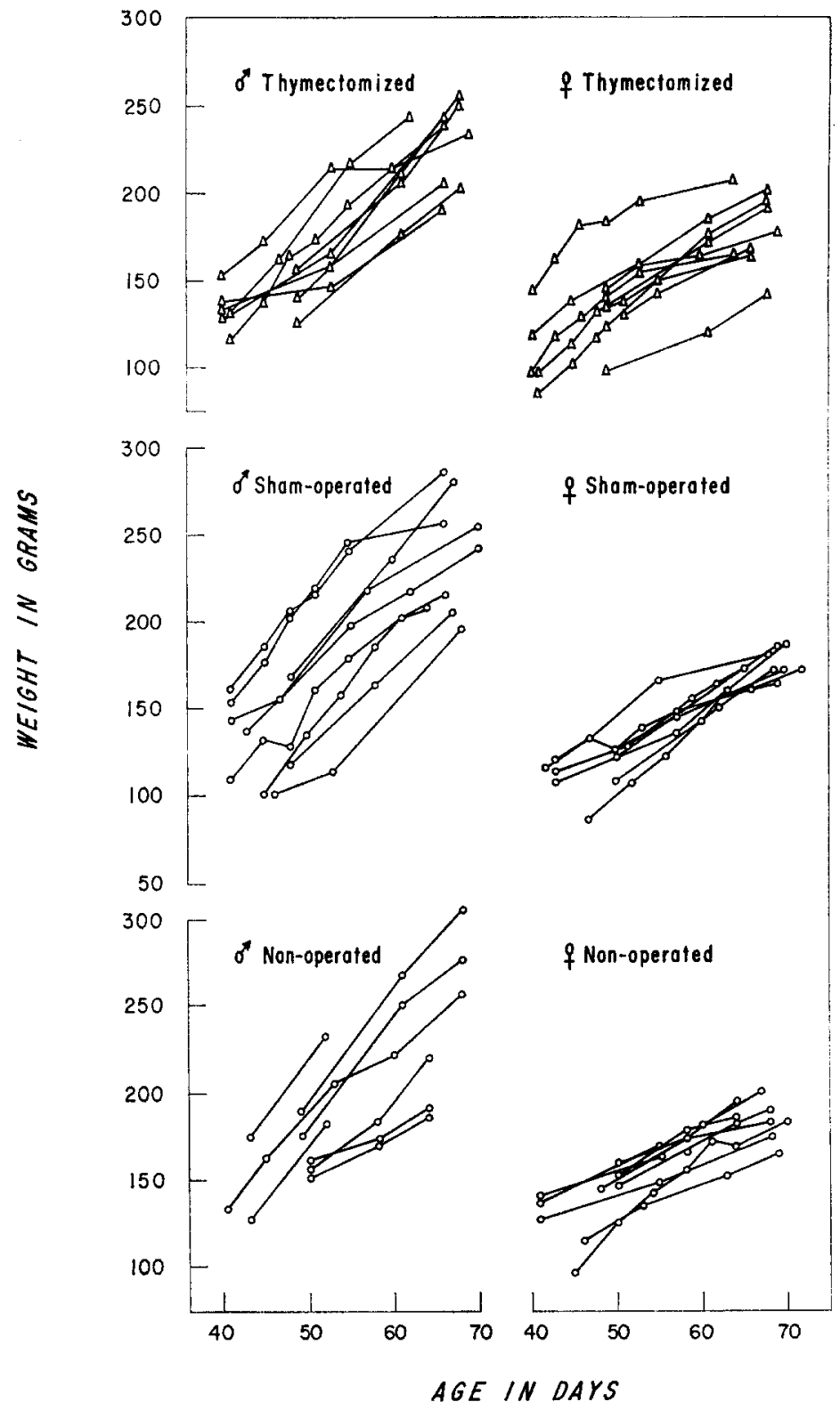

TEXT-FIG. 1. Growth curves of rats from representative litters showing failure of thymectomy to affect weight gain. 


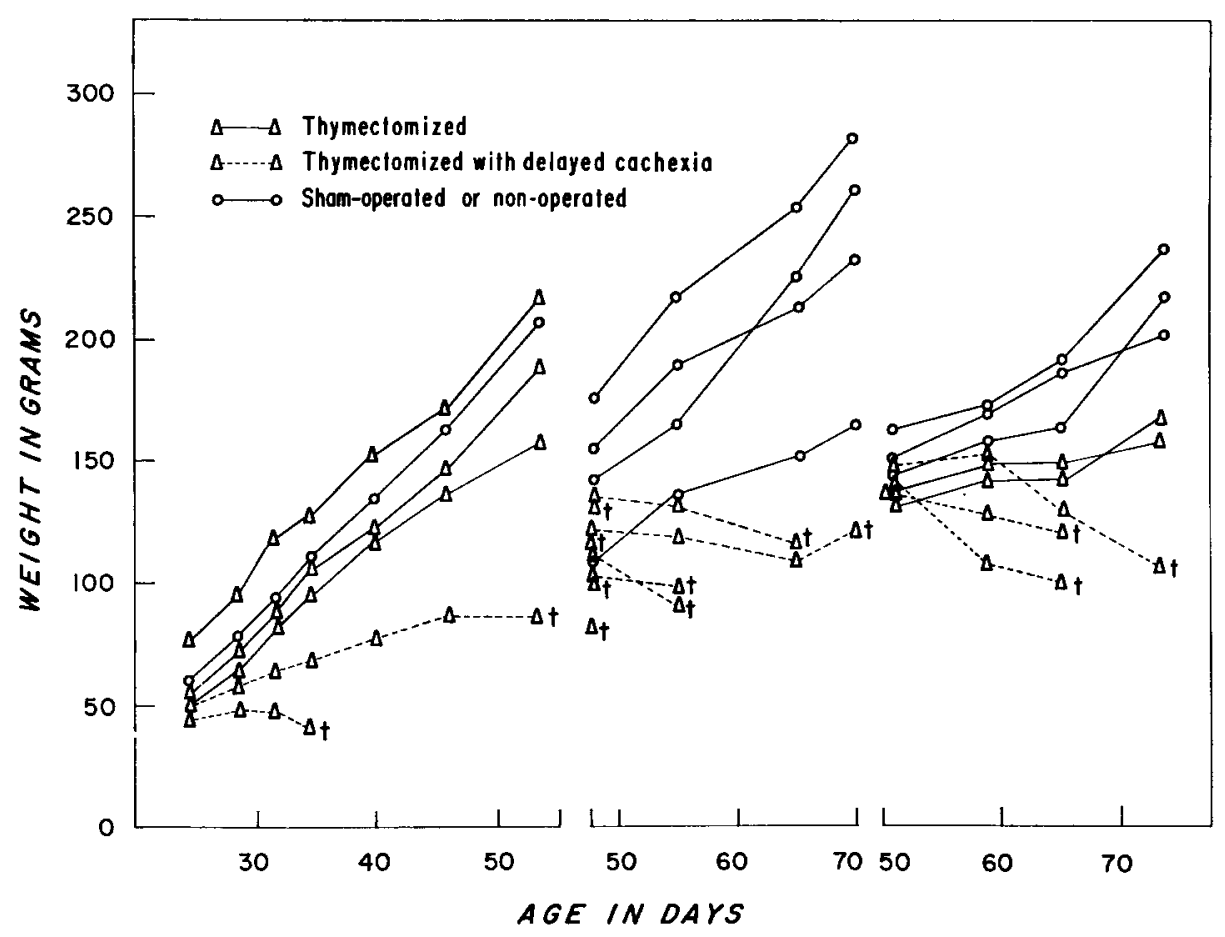

Text-Fig. 2. Growth curves of rats from individual litters in which wasting disease (cachexia) developed at different times (left and right). Not all the thymectomized rats were affected. Curves in center are from two litters of identical age, pooled at the time of weaning: here all thymectomized rats of both litters were affected.

TABLE I

Relation of Arthus Reaction to Humoral Antibody in Thymectomized and Control Animals

\begin{tabular}{|c|c|c|c|c|c|c|c|c|c|c|c|}
\hline \multirow{2}{*}{ Category* } & \multirow{2}{*}{$\begin{array}{l}\text { No. of } \\
\text { rats }\end{array}$} & \multicolumn{2}{|c|}{$\begin{array}{l}\text { Average diameter of } \\
\text { Arthus reaction }\end{array}$} & \multicolumn{7}{|c|}{$\begin{array}{l}\text { No. of sera with hemaggluti- } \\
\text { nation titer at } 3-4 \text { weeks } \ddagger\end{array}$} & \multirow{2}{*}{$\begin{array}{l}\text { No. with } \\
\text { positive } \\
\text { precipiti }\end{array}$} \\
\hline & & 9-12 days & 19-21 days & $\leq 4$ & 8 & 16 & 32 & 64 & 128 & $\geq 256$ & \\
\hline & & $m m$ & $m m$ & & & & & & & & \\
\hline \multicolumn{12}{|l|}{ Thymectomized: } \\
\hline Arthus-negative & 8 & 1.2 & 1.1 & 5 & 0 & 4 & 0 & 0 & 0 & 0 & $0 / 8$ \\
\hline Arthus-positive $\$$. & 11 & 2.6 & 11 & 0 & 0 & 0 & 3 & 1 & 6 & 4 & $9 / 9$ \\
\hline Sham-operated ... & 18 & 13 & 13 & 0 & 0 & 0 & 4 & 3 & 9 & 3 & $10 / 10$ \\
\hline Non-operated. . & 18 & 12 & 13 & 0 & 0 & 2 & 6 & 2 & 4 & 4 & - \\
\hline
\end{tabular}

* About half the rats in each category were injected with thymus or spleen extract during sensitization.

$\ddagger$ Baseline titer was 0 in all of thirty-two preimmunization sera tested.

$\$$ Reactions $\geq 8 \mathrm{~mm}$. 
before and during the sensitization period to about half the animals, both thymectomized and controls. This procedure had no apparent effect on antibody formation and Arthus reactivity; the data therefore have been combined in the table with data obtained in rats not so treated. "Natural" heteroag. glutinins were not reduced in thymectomized rats (Table II).
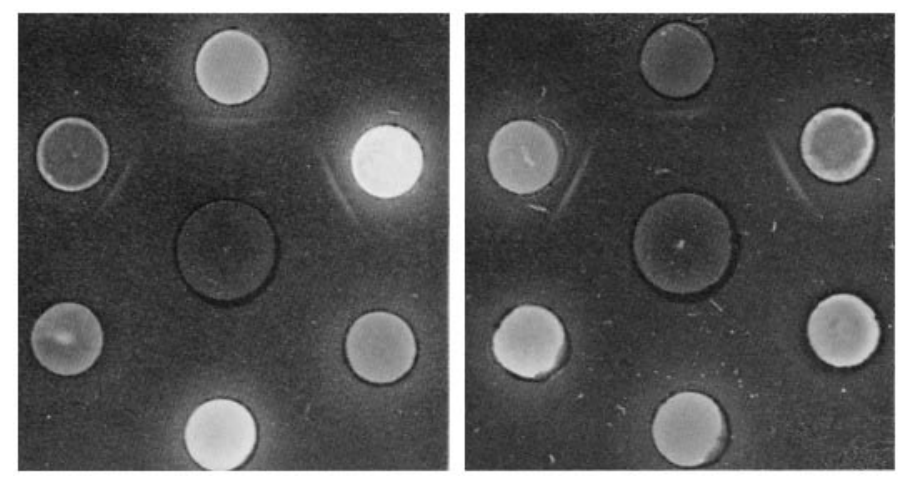

TExt-Fig. 3. Precipitation in gel of antibody to BSA; six different control sera (top) and six sera of thymectomized rats (bottom) after 24 hour diffusion against BSA $(50 \mathrm{mg} / \mathrm{ml})$ in center walls. Only the control sera give precipitation, each showing a single line of precipitate.

TABLE II

Natural Heteroagghuinins in Unsensitized Thymectomised and Control Rats

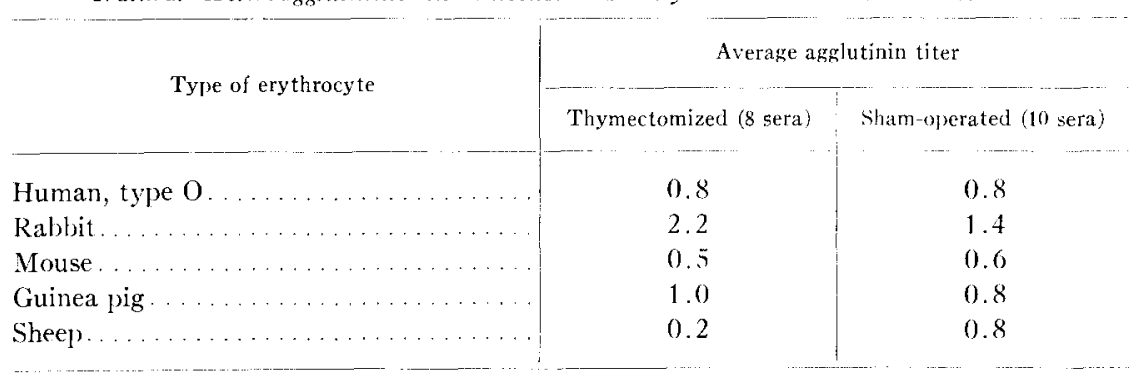

Delayed Reactions to BSA.- Rats sensitized with BSA plus adjuvant develop typical delayed reactions with deep induration and a variable degree of central necrosis, maximal at 24 hours, when skin-tested with BSA. However, rats thymectomized during the 1st week of life showed an appreciable diminution of the delayed response when sensitized at 8 weeks of age. Inspection of 'Table III shows that three out of twenty-one thymectomized rats had 24 hour delayed reactions greater than $10 \mathrm{~mm}$ in diameter, when tested 9 to 12 days after sensitization; sixteen out of eighteen controls had delayed reactions greater than $10 \mathrm{~mm}$ at this time. The degree of induration (not shown in the table) 
was also much reduced in thymectomized rats. Sham-operated and nonoperated litter mates showed reactions, identical in diameter and in degree of induration to those of randomly selected non-litter mate controls of like age. By 19 to 21 days 9 out of 21 thymectomized animals had developed significant delayed sensitivity to BSA, but even at this late date the remaining rats failed to do so. This would seem to establish that, at least in some animals delayed reactive capacity, while compromised, is not totally abolished. It is of interest to note that sensitivity of control animals had passed its acme and begun to wane by 21 days, even while that of thymectomized animals was increasing. Treatment with homogenates of thymus or spleen, injected before and

TABLE III

Effect of Thymectomy on Delayed Skin Reaction to BSA

\begin{tabular}{|c|c|c|}
\hline \multirow{2}{*}{ Category } & \multicolumn{2}{|c|}{$24 \mathrm{hr}$. reactions to $30 \mu \mathrm{g} \mathrm{BSA}$} \\
\hline & $9-12$ days & 19-21 days \\
\hline & $m m$ & $m m$ \\
\hline \multicolumn{3}{|l|}{ Thymectomized } \\
\hline Untreated.... & $0,0,0,0,0,0,2,2,13,16$ & $0,0,0,0,0,4,10,12,12,13$ \\
\hline Thymus extract. & $0,0,2,3,8$ & $0,4,7,10,12$ \\
\hline Spleen extract... & $0,0,7,8,9,11$ & $0,5,7,10,11,13$ \\
\hline Sham-operated. . & $11,11,13,15,16,17$ & $8,9,9,9,11$ \\
\hline Non-operated. & $0,12,15,16,16$ & $7,7,11,12,14$ \\
\hline Non-litter mate control & $4,12,14,15,15,18,18$ & $6,11,11,12,12,12,14$ \\
\hline
\end{tabular}

during the sensitization period, did not enhance to any appreciable extent the impaired delayed reactive capacity of thymectomized animals.

Effect of Thymectomy at 2 to 3 Weeks.-The Arthus and delayed reactions of rats thymectomized at 2 to 3 weeks of age are shown in Table IV. By 9 to 10 days eight out of twelve of the thymectomized rats had positive Arthus reactions of intensity comparable to those in control rats. The remaining animals remained Arthus-negative through the 16th day. All thymectomized rats developed some degree of delayed reactivity. It was considerably reduced in comparison with the reactivity of control rats at 9 to 10 days, but less strikingly so at 16 days.

Effect of Splenectomy.-Splenectomy shortly after birth in a group of six rats failed to affect the later development of either Arthus or delayed reactivity to BSA as compared with fourteen sham-operated controls.

Delayed Reactions to Ea in Guinea Pigs Thymectomized as Adults.-There was no inhibition of delayed sensitization in adult guinea pigs sensitized with Ea-anti-Ea specific precipitate 2 weeks after thymectomy (Table V).

Electrophoresis and Characterization of Anti-BSA Antibody in Rats.-In 
the sera studied thus far, hemagglutinating and precipitating antibody activities were closely parallel. In all sera examined, the antibody gave a single line in Ouchterlony plates (Text-fig. 3). An attempt to identify the precipitating

TABLE IV

Effect of Thymectomy at 2-3 Weeks of Age* on Arthus and Delayed Reactions to BSA

\begin{tabular}{|c|c|c|c|c|c|}
\hline \multirow{2}{*}{ Category } & \multirow{2}{*}{ No. of rats } & \multicolumn{2}{|c|}{$\begin{array}{c}\text { Average diameter of } \\
\text { Arthus reaction }\end{array}$} & \multicolumn{2}{|c|}{ 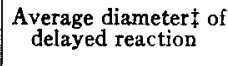 } \\
\hline & & $9-10$ days & 16 days & $9-10$ days & 16 days \\
\hline Thymectomized & & & & & \\
\hline Arthus-negative . & 4 & 3 & 3 & 6 & 9 \\
\hline Arthus-positive $\$$. & 8 & 10 & 12 & 11 & 11 \\
\hline Sham-operated. & 8 & 10 & 14 & 15 & 12 \\
\hline Non-operated. . & 15 & 13 & 14 & 17 & 12 \\
\hline
\end{tabular}

* Nine rats thymectomized at 2 weeks and five at 3 weeks.

$\ddagger$ Diameter of induration at 24 hours.

$\S$ Reactions $\geq 8 \mathrm{~mm}$ in diameter.

TABLE V

Failure of Thymectomy in Adult Guinea Pigs to Affect Delayed Sensitization with Specific Precipitates of $E a^{*}$

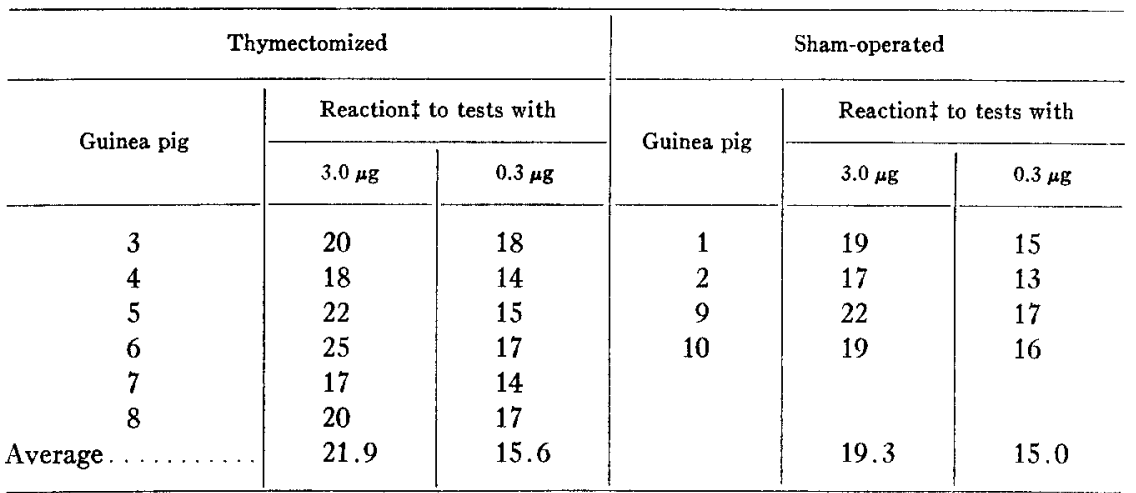

* Adult guinea pigs, thymectomized and sensitized 2 weeks later by injection of Ea-anti Ea specific precipitate in Freund's adjuvant.

$\ddagger 24$ hour reactions to skin tests with 3.0 and $0.3 \mu \mathrm{g} \mathrm{Ea}$.

antibody by moving boundary electrophoresis of serum, from which antibody had been removed by serial absorption with BSA, was unsuccessful (Text-fig. 4). Average values for serum albumin and for $\alpha-, \beta$ - , and $\gamma$-globulins determined by paper electrophoresis are shown in Table VI. No significant difference could be found among thymectomized, partially thymectomized, and sham-operated rats with regard to any of the major plasma protein components measured. 


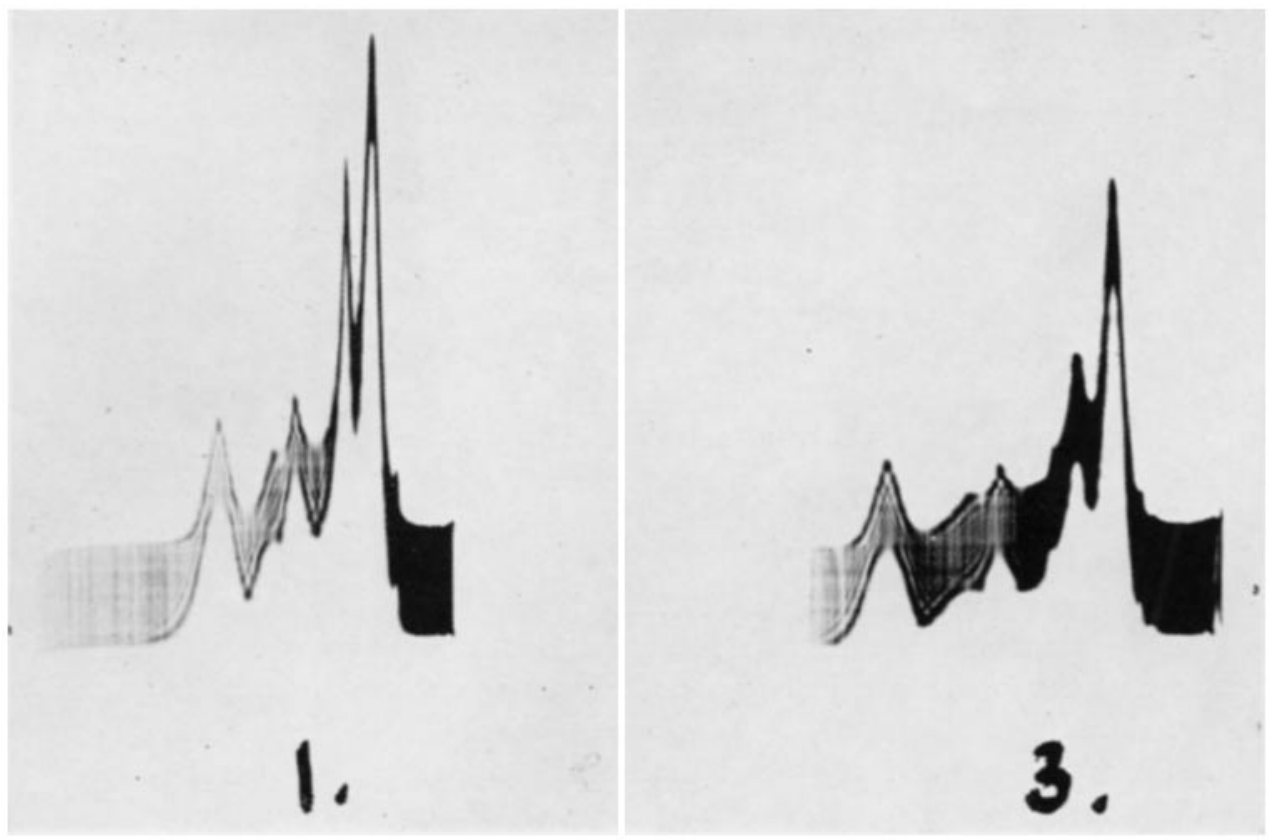

Text-Fig. 4. Ascending electrophoretic pattern of pooled antiserum from two control rats with high titer of anti-BSA, before (left) and after removal of antibody by precipitation with $50 \mu \mathrm{g}$ of BSA. The percentages calculated from these patterns were:

\begin{tabular}{|c|c|c|c|c|}
\hline & Albumin & $\alpha$ & $\beta$ & $\gamma$ \\
\hline Before... & 51 & 27 & 14 & 8 \\
\hline After $\ldots \ldots \ldots \ldots \ldots \ldots \ldots \ldots$ & 47 & 31 & 15 & 7 \\
\hline
\end{tabular}

TABLE VI

Serum Protein Values* in Rats Thymectomized at Birth

\begin{tabular}{|c|c|c|c|c|c|}
\hline \multirow{2}{*}{ Category } & \multirow{2}{*}{$\begin{array}{c}\text { No. of } \\
\text { rats }\end{array}$} & \multicolumn{4}{|c|}{ Per cent of total protein } \\
\hline & & Albumin & $\alpha$ & $\beta$ & $\gamma$ \\
\hline Thymectomized $\ddagger$. & 14 & 48.3 & 27.1 & 15.3 & 9.3 \\
\hline $\begin{array}{l}\text { Thymectomized, but residual thymus } \\
\text { or reacted } \ldots \ldots \ldots \ldots \ldots \ldots \ldots\end{array}$ & 10 & 50.6 & 25.4 & 14.2 & 9.2 \\
\hline Sham-operated . . . . . . . . . & 15 & 47.1 & 28.1 & 12.7 & 12.1 \\
\hline Non-operated. & 10 & 47.6 & 26.8 & 14.1 & 11.5 \\
\hline
\end{tabular}

* All sera taken before administration of antigenic stimulus.

$\ddagger$ Less than $100 \mathrm{mg}$ residual thymus. 
Chemically Induced Inflammation.--Turpentine in olive oil, injected intradermally in both thymectomized and control rats, produced erythema and induration, which reached 11 to $14 \mathrm{~mm}$ diameter by 24 hours, and minimal necrosis. Evans blue, injected intradermally, gave a blue spot which increased in diameter to reach 20 to $25 \mathrm{~mm}$ at 24 hours. With neither of these indices did the thymectomized animals show a difference from the controls. As will be shown in our next paper, the local passive transfer of tuberculin sensitivity was accepted equally well by experimental and control rats.

DISCUSSION

The normal weight gain and general good health of most of our thymectomized rats are in accordance with earlier observations $(26,27)$. The wasting disease which afflicted these animals in certain cages appears comparable to the "thymic cachexia" which has plagued investigators of thymic function over the years $(28,29$, and many others). In our experiments, most litters escaped this illness; but in a few, every thymectomized member eventually succumbed, individual animals being affected seriatim. The onset varied from as early as 20 days to as late as 60 days. These observations suggest that thymic cachexia may be a chronic infectious process of undetermined type. Thymectomized rats which escaped cachectic disease in infected cages may have had ectopic thymic tissue or residual immunologic competence on some other basis.

The rat has been widely regarded as unsuitable for the study of conventional immunological reactions. The studies of Freund and Stone have implied that special techniques were required to induce Arthus reactions in this species (30), and delayed reactivity of the tuberculin type has been generally supposed not to occur (see review in reference 31 ). We have recently shown that intense delayed sensitivity to protein antigens is readily induced by the use of suitable adjuvant mixtures and the foot-pad route of inoculation (21). The present study shows that the same technique is highly effective in inducing antibody formation and Arthus reactivity. The Arthus reactions in the rat were closely similar, in time course and in gross and histological character, to Arthus reactions described in other species and, as in other species (32), were exactly correlated with the presence of precipitating antibody.

It is clear, from the data we have presented, that rats, thymectomized during the 1st week of life, have a markedly impaired capacity to develop Arthus sensitivity to BSA and have a low titer of precipitating and hemagglutinating antibody against this antigen. Those rats which gave an immune response still had lymphocytes in their lymphoid tissues (33); i.e., were not effectively depleted. Yet even in these animals there was a marked delay in the appearance of sensitization. Our data thus agree with the finding of Archer and Pierce (10) 
that rabbits, thymectomized at birth and presumably healthy thereafter, show an impaired ability to make antibody against BSA.

It would be premature, however, from studies on a single antigen-antibody system, to infer that all types of antibody formation are suppressed in thymectomized animals. "Natural" heteroagglutinin titers, though very low, in agreement with the findings of others (34), were found to be identical in thymectomized and control rats. Our attempt to characterize the anti-BSA antibody, formed in control but not in thymectomized animals, was unsuccessful. Mice injected with BSA in complete adjuvant form an antibody of $\beta$-mobility (35), and there is now evidence that the rat antibody is of the same type (35a). However, both $\beta$ - and $\gamma$-globulins were present in the sera of our thymectomized rats in undiminished titer. Absorption of antiserum by removal of precipitating antibody gave no measurable change in any of the protein peaks. Finally the lymphoid tissues of the thymectomized rats contained normal complements of plasma cells and germinal center cells (33), both of which have been clearly shown to produce $\gamma$-globulin antibody $(36,37)$ and perhaps antibody of other types as well (38). It is possible that lymphocytes or cells of the lymphocyte line are capable of making certain antibodies. There is evidence that $19 \mathrm{~S}$ macroglobulin $(\beta 2 \mathrm{M})$ antibodies are formed in cells resembling large or small lymphocytes (39), and the macroglobulin of Waldenström's macroglobulinemia is apparently made by a "lymphoid plasma cell," which may in truth belong to the lymphocyte series $(40)$. The deficiency in the antibody-forming mechanism of the thymectomized rat may conceivably be concerned with such 19S antibodies or with some other as yet uncharacterized antibody system. It is apparent that a full evaluation of the effect of early thymectomy on antibody formation will only be possible when a variety of antigen-antibody systems have been studied in thymectomized animals with a complete evaluation, not only of the amount, but also of the molecular character of each antibody studied.

The striking loss of ability of thymectomized rats to develop delayed reactivity to BSA is in agreement with evidence showing a similar diminution in other types of delayed response $(11,12,41)$. We cannot review here evidence implicating the lymphocyte as the essential cell in the initiation and expression of delayed hypersensitivity (see reference $\mathbf{4 2}$ for review). It is now well established that animals depleted of lymphocytes, whether by non-specific or specific means, have diminished delayed hypersensitive responses $(43,44)$. The thymectomized rat is greatly depleted of small lymphocytes, both in the blood (41) and in the spleen and lymph nodes (33). We relate the compromised delayed responsiveness of thymectomized rats to this deficiency in potentially sensitizable or reactive cells. Those thymectomized animals whose reactive capacity was least showed the greatest depletion of lymphocytes, both in blood and lymphoid organs, whereas those whose reactive capacities were less affected showed a less 
striking depletion of these cells (33). The failure of splenectomy to influence reactions to BSA agrees with earlier experiments (45) showing the failure of splenectomy to influence tuberculin sensitivity adversely, and points up the fact that the effect of thymic extirpation does not depend simply on the removal of a large amount of lymphoid tissue.

The small lymphocyte responsible for delayed reactive capacity would seem to originate primarily in the thymus (5). The failure of thymus or spleen homogenates, in large doses, to restore the ability of thymectomized rats to develop delayed sensitivity argues strongly against any significant role for lymphocytopoietic hormonal factors of thymic origin such as the thymic lymphocytosisstimulating factor described by Metcalf (46). In experiments complementary to ours, Miller (11) has shown that replacement by grafting of intact, viable thymus, in mice thymectomized at birth, restores their reactive capacity against homograft antigens.

Rats thymectomized at 2 to 3 weeks of age showed a less striking loss of delayed reactivity than rats thymectomized at birth; guinea pigs thymectomized as adults showed none at all. Miller (11) and Martinez et al. (12) have shown, similarly, that thymectomy of adult mice fails to affect their ability to reject homografts, though thymectomy as late as 30 days was minimally effective (12). A possible explanation for this finding might be that the responsibility for making and delivering small lymphocytes is, in early life, an exclusive property of the thymus but that, as the animal matures, this responsibility is passed on to an increasing extent to other organs such as lymph nodes and spleen. An alternative explanation might be that the thymus retains its function as a source organ of small lymphocytes throughout life but that, after its extirpation, a considerable interval of time must elapse before the body is depleted of the now irreplaceable supply of small lymphocytes. The long life span of the lymphocyte seems to be clearly established (47). In animals, past the peak of their growth curves, in which significant dilution of a finite cell population by growth alone is excluded, lymphocyte depletion sufficient to impair delayed reactive capacity significantly could conceivably require several months. This possibility is at present being investigated.

\section{SUMMARY AND CONCLUSIONS}

Rats thymectomized at birth gained weight and otherwise developed normally, but were found to be very susceptible to intercurrent infections. Both Arthus reactivity and delayed hypersensitivity to BSA were markedly impaired in rats thymectomized during the first week of life and significantly impaired in rats thymectomized as late as 3 weeks after birth. The inhibition of Arthus reactivity in thymectomized rats was well correlated with their failure to develop significant titers of precipitating or hemagglutinating antibody. However, natural heteroagglutinin titers were not altered in these animals, and no ab- 
normality of serum proteins, including $\gamma$-globulin, could be detected by paper electrophoresis. The loss of immunologic activity could not be corrected by injecting homogenates of spleen or thymus before and during the sensitization period. Splenectomy at birth did not influence Arthus or delayed reactivity.

The authors would like to thank Dr. Sidney Leskowitz and Dr. Karl Schmid for their assistance in carrying out the moving boundary and paper electrophoreses, and to express their gratitude to Anne Newton for carrying out many of the thymectomies reported in the present study.

\section{BIBLIOGRAPHY}

1. Stavitsky, A. B., In vitro studies of the antibody response, Advances Immunology, 1961, 1, 211.

2. Thorbecke, G. J., and Benacerraf, B., The reticulo-endothelial system and immunological phenomena, Progr. Allergy, 1962, 6, 559.

3. Lawrence, H. S., Delayed sensitivity and homograft sensitivity, Ann. Rev. Med., $1960,11,207$.

4. Waksman, B. H., Delayed hypersensitive reactions: A growing class of immunologic phenomena, J. Allergy, 1960, 31, 468.

5. Arnason, B. G., Janković, B. D., and Waksman, B. H., A survey of the thymus and its relation to lymphocytes and immune reactions, Blood, 1962, in press.

5a. Auerbach, R., Morphogenetic interactions in the development of the mouse thymus gland, Develop. Biol., 1960, 2, 271.

6. Harris, T. N., Rhoads, J., and Stokes, J., Jr., A study of the role of the thymus and spleen in the formation of antibodies in the rabbit, J. Immunol., 1948, $58,27$.

7. MacLean, L. D., Zak, S. J., Varco, R. L., and Good, R. A., The role of the thymus in antibody production: An experimental study of the immune response in thymectomized rabbits, Transplant. Bull,, 1957, 4, 21.

8. Hammar, J. A., Experimentelle Untersuchung über die Rolle der Thymus bei der Immunisierung, Z. mikroskop.-anat. Forsch., 1938, 44, 425.

9. Fichtelius, K. E., Laurell, M., and Philipsson, L., The influence of thymectomy on antibody formation, Acta Path. Microbiol. Scand., 1961, 51, 81.

10. Archer, O., and Pierce, J. C., Role of thymus in development of the immune response, Fed. Proc., 1961, 20, 26 (abstract).

11. Miller, J. F. A. P., Immunological function of the thymus, Lancet, 1961, 2, 748.

12. Martinez, C., Kersey, J., Papermaster, B. W., and Good, R. A., Skin homograft survival in thymectomized mice, Proc. Soc. Exp. Biol. and Med., 1962, 109, 193.

13. Arnason, B. G., Janković, B. D., and Waksman, B. H., Effect of thymectomy on "delayed" hypersensitive reactions, Nature, 1962, 194, 99.

14. Ackerman, C. A., and Knouff, R. A., Lymphocytopoiesis in the bursa of Fabricius, Am. J. Anat., 1959, 104, 163.

15. Fennell, R. A., and Pearse, A. G. E., Some histochemical observations on the bursa of Fabricius and thymus of the chicken, Anat. Rec., 1961, 139, 93.

16. Mueller, A. P., Wolfe, H. R., and Meyer, R. K., Precipitin production in 
chickens. XXI. Antibody production in bursectomized chickens and in chickens injected with 19-nortestosterone on the 5th day of incubation, J. Immunol, $1960,85,172$.

17. Meyer, R. K., and Wolfe, H. R., 1962, personal communication.

18. Glick, B., The influence of dipping eggs in male hormone solutions on lymphatic tissue and antibody response of chickens, Endocrinology, 1961, 69, 984.

19. Papermaster, B. W., Friedman, D. I., and Good, R. A., Modification of the homograft response in young chicks with 19-nortestosterone, Fed. Proc., 1961, 20, 36 (abstract).

20. Park, E. A., Extirpation of the thymus in the guinea pig, J. Exp. Med., 1917, $25,129$.

21. Flax, M. H., and Waksman, B. H., Delayed cutaneous reactions in the rat, $J$. Immunol., 1962, in press.

22. Uhr, J. W., Salvin, S. B., and Pappenheimer, A. M., Jr., Delayed hypersensitivity. II. Induction of hypersensitivity in guinea pigs by means of antigen-antibody complexes, J. Exp. Med., 1957, 105, 11.

23. Csizmas, L., Preparation of formalinized erythrocytes, Proc. Soc. Exp. Biol. and Med., 1960, 103, 157.

24. Stavitsky, A. B., and Arquilla, E. R., Studies of proteins and antibodies by specific hemagglutination and hemolysis of protein-conjugated erythrocytes, Internat. Arch. Allergy and Appl. Immunol., 1958, 13, 1.

25. Ouchterlony, O., Diffusion-in-gel methods for immunological analysis, Progr. Allergy, 1958, 5, 1.

26. Gordon, H. A., Morphological and physiological characterization of germ-free life, Ann. New York Acad. Sc., 1959, 78, 208.

27. Metcalf, D., The effect of thymectomy on the lymphoid tissues of the mouse, Brit. J. Haematol., 1960, 6, 324.

28. Klose, H., and Vogt, H., Klinik und Biologie der Thymusdrüse mit besonderer Berücksichtigung ihrer Beziehungen zu Knochen-und Nervensystem, Beitr. klin. Chir., 1910, 69, 1.

29. Comsa, C., Consequences of thymectomy upon the leucopoiesis in guinea pigs, Acta Endocrinol., 1957, 26, 361.

30. Freund, J., and Stone, S. H., Arthus reaction in the mouse and the rat after intralabial injection of antigens, $J$. Immunol., 1956, 76, 138.

31. Crowle, A. J., Delayed hypersensitivity in mice, J. Allergy, 1959, 30, 151.

32. Benacerraf, B., and Kabat, E. A., A quantitative study of the Arthus phenomenon induced passively in the guinea pig, $J$. Immunol., 1950, 64, 1 .

33. Waksman, B. H., Arnason, B. G., and Janković, B. D., Role of the thymus in immune reactions in rats. III. Changes in the lymphoid organs of thymectomized rats, J. Exp. Med., 1962, 116, 187.

34. Wagner, M., Serologic aspects of germ-free life, Ann. New York Acad. Sci., 1959, 78, 261.

35. Jordan, R. T., Banovitz, J., Trapani, I. L., and Campbell, D. H., Electrophoretic analysis of serum and ascitic fluid proteins from immunized and non-immunized mice, J. Immunol., 1962, 88, 314.

35 a. Banovitz, J., Jordan, R. T., and Trapani, I. L., Electrophoretic analyses of 
serum and ascitic fluid proteins from mice, guinea pigs and rats, Fed. Proc., 1962, 21, 20 (abstract).

36. Coons, A. H., Leduc, E. H., and Connolly, J. M., Studies on antibody production. I. A method for the histochemical demonstration of specific antibody and its application to a study of the hyperimmune rabbit, J. Exp. Med., 1955, 102, 49.

37. Ortega, L. G., and Mellors, R. C., Cellular sites of formation of gamma globulin, J. Exp. Med., 1957, 106, 627.

38. Potter, M., and Fahey, J. L., Studies on eight transplantable plasma-cell neoplasms of mice, J. Nat. Cancer Inst., 1960, 24, 1153.

39. Smith, R. T., Response to active immunization of human infants during the neonatal period, in Ciba Foundation Symposium on Cellular Aspects of Immunity, (G. E. W. Wolstenholme and M. O'Connor, editors), London, J. and A. Churchill, Ltd., 1960, 348.

40. Dutcher, T. F., and Fahey, J. L., The histopathology of the macroglobulinemia of Waldenström, J. Nat. Cancer Inst., 1959, 22, 887.

41. Arnason, B. G., Janković, B. D., Waksman, B. H., and Wennersten, C., Role of the thymus in immune reactions in rats. II. Suppressive effect of thymectomy at birth on reactions of delayed (cellular) hypersensitivity and the circulating small lymphocyte, J. Exp. Med., 1962, 116, 177.

42. Waksman, B. H., A comparative histopathological study of delayed hypersensitive reactions, in Ciba Foundation Symposium on Cellular Aspects of Immunity, (G. E. W. Wolstenholme and M. O'Connor, editors), London, J. and A. Churchill, Ltd., 1960, 280.

43. Waksman, B. H., Arbouys, S., and Arnason, B. G., The use of specific lymphocyte antisera to inhibit hypersensitive reactions of the delayed type, J. Exp. Med., 1961, 114, 997.

44. Pepys, J., The relationship of non-specific and specific factors in the tuberculin reaction. A review, Am. Rev. Tuberc., 1955, 71, 49.

45. Freund, J., On the role of the reticulo-endothelial system in the tuberculin hypersensitiveness, J. Immunol., 1926, 11, 383.

46. Metcalf, D., The thymic lymphocytosis stimulating factor, Ann. New York Acad. Sc., 1958, 73, 113.

47. Ottesen, J., On the age of human white cells in peripheral blood, Acta Physiol. Scand., 1954, 32, 74. 
EXPLANATION OF PLATE 12

FIgs. $1 a$ to $1 \mathrm{c}$. Arthus reaction at 4 hours in sham-operated rat, sensitized with BSA and adjuvant and skin-tested at 20 days with $30 \mu \mathrm{g}$ BSA. Fig. $1 a$ shows extensive edema and cellular infiltration in deep dermis, muscle, and subcutaneous connective tissue. Figs. $1 b$ and $1 c$ show vascular occlusion by leukocytic thrombi and massive infiltration of polymorphonuclear leukocytes. All hematoxylin and eosin. Fig. $1 a$, $\times 32$, Fig. $1 b, \times 120$, Fig. $1 c, \times 260$. 

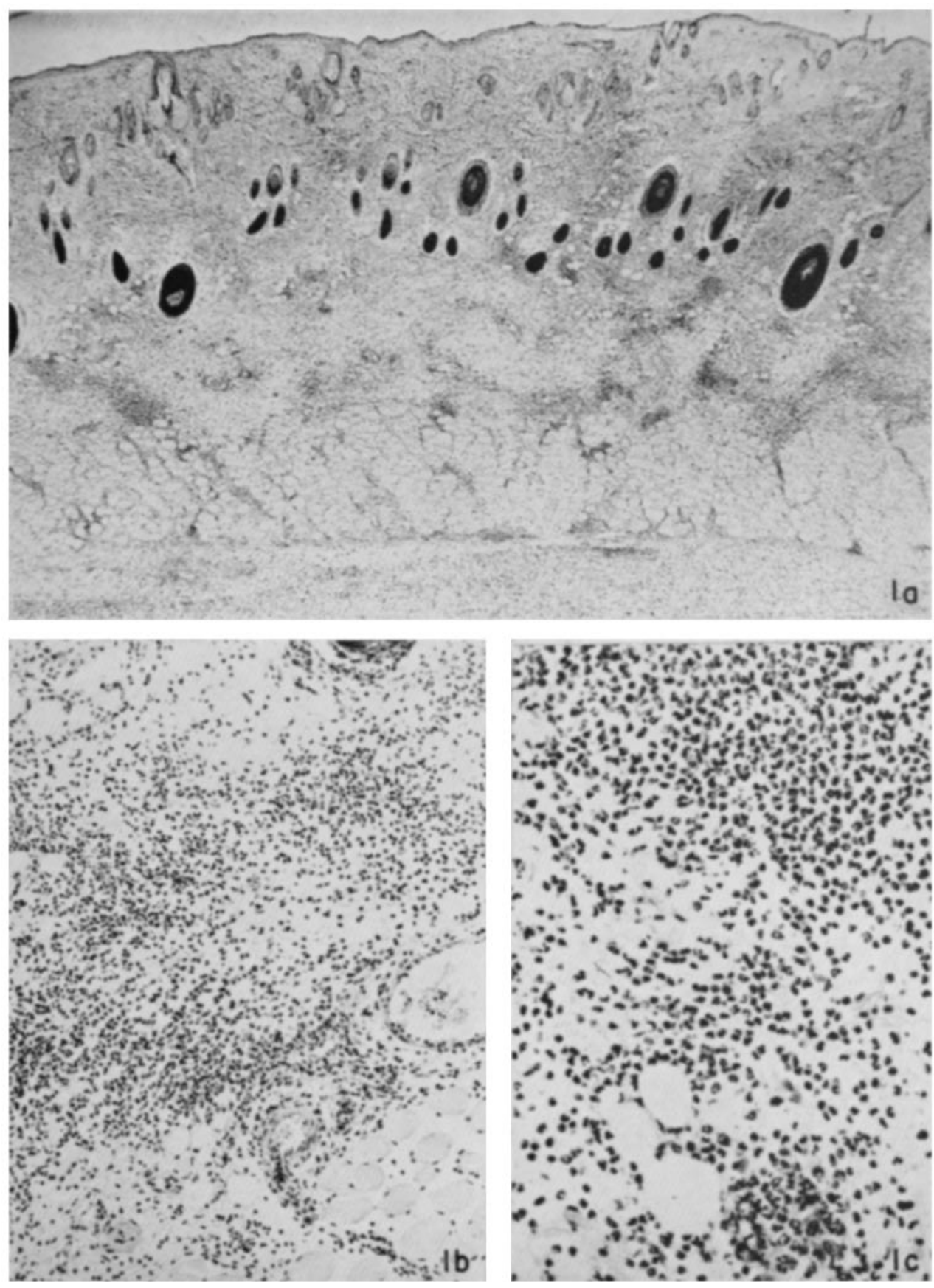

(Jankovic el al.: Thymus role in immune reactions in rats. I) 